\title{
Changes in microbiological attributes of a Red Latosol under different cropping systems
}

\section{Alterações dos atributos microbiológicos em um Latossolo Vermelho sob diferentes sistemas de manejo}

\author{
Deisi Navroski ${ }^{*}$; Adônis Moreira ${ }^{2}$; Maria de Fátima Guimarães 3 ; \\ Arnaldo Colozzi Filho ${ }^{4}$
}

\begin{abstract}
The objective of this study was to evaluate changes in microbiological attributes of soils under different growing systems. Three cropping systems were evaluated (1) no-tillage system (NTS); (2) conventional tillage system (CTS); and (3) newly scarified no-tillage system (SNTS). The three systems were maintained for 20 years. In addition, a primary forest $(\mathrm{PF})$ fragment was used as a reference. Soil samples were collected at depths of $0.0-0.1 \mathrm{~m}, 0.1-0.2 \mathrm{~m}$, and $0.2-0.3 \mathrm{~m}$. The following variables were measured: microbial biomass carbon (MBC); soil respirometry (RESP) using the fumigation and incubation method; microbial biomass nitrogen (MBN) using fumigation and extraction; metabolic quotient $\left(q \mathrm{CO}_{2}\right)$ using the RESP/MBC ratio; and number of spores (NS) of mycorrhizal fungi by plate counting of spores extracted from the soil by wet sieving. Treatments were arranged in a completely randomized block design with five replicates. The different management systems affected the soil microbiota, especially in the superficial layer of $0.0-0.1 \mathrm{~m}$. At a depth of $0.0-0.2 \mathrm{~m}$, the PF presented significantly higher values for all analyzed attributes, except for NS. There were no significant differences in the studied characteristics between the NTS and SNTS at the three depths, indicating that scarification performed only once in the NTS was not sufficient to produce changes in soil microbiological attributes. However, the adoption of the CTS for 20 years promoted a decrease in MBC and MBN. RESP and NS were not significantly different between the cropping systems. Principal component analysis indicated a significant difference in microbiological characteristics between the PF and the areas under management. Therefore, different growing systems change the soil microbiota, and the lower the degree of tilling (NTS and SNTS), the smaller the changes in soil microbiological attributes. Soil preparation practices used in conventional tilling negatively affect soil microbial biomass, decreasing the levels of $\mathrm{MBC}$ and $\mathrm{MBN}$.
\end{abstract}

Key words: Conventional tillage. Microbial carbon. Metabolic quotient. Mycorrhizae. No-tillage.

\section{Resumo}

O objetivo deste trabalho foi avaliar alterações nos atributos microbiológicos do solo em diferentes sistemas de manejo. Avaliou-se três tipos de manejo de solo (1) sistema de plantio direto -SPD; (2)

\footnotetext{
${ }^{1}$ Eng $^{\mathrm{a}}$ Agr ${ }^{\mathrm{a}}$, Discente, Curso de Mestrado, Programa de Pós-Graduação em Agronomia, Universidade Estadual de Londrina, UEL, Londrina, PR, Brasil. E-mail: deisinavroski@gmail.com

2 Pesquisador Dr., Empresa Brasileira de Pesquisa Agropecuária, EMBRAPA Soja, Londrina, PR, Brasil. E-mail: adonis.moreira@ embrapa.br

3 Prof ${ }^{\mathrm{a}}$ Dra $^{\mathrm{a}}$, Programa de Pós-Graduação em Agronomia, UEL, Departamento de Agronomia, Londrina, PR, Brasil. E-mail: mfatima@uel.br

4 Pesquisador Dr., Instituto Agronômico do Paraná, IAPAR, Londrina, PR, Brasil. E-mail: acolozzi@iapar.br

* Author for correspondence
} 
plantio convencional - PC, ambos estabelecidos a 20 anos e (3) sistema de plantio direto de 20 anos recém escarificado - SPDE. Além desses, um fragmento de floresta primária (FP) foi usado como referência. Amostras de solo foram coletadas nas profundidades de $0,0-0,1 ; 0,1-0,2$ e 0,2 - 0,3 $\mathrm{m}$ e determinados o carbono da biomassa microbiana (CBM) e a respirometria do solo (RESP) pelo método da fumigação e incubação, o nitrogênio da biomassa microbiana (NBM) determinado por fumigação e extração, o quociente metabólico $\left(q \mathrm{CO}_{2}\right)$ pela razão entre RESP/CBM, e o número de esporos de fungos micorrízicos (nESP) por contagem em placa sob microscópio dos esporos extraídos do solo por peneiramento úmido. Os dados foram analisados como delineamento inteiramente ao acaso com cinco repetições. Os diferentes manejos influenciaram a microbiota do solo, destacadamente na camada superficial de solo $0,0-0,1 \mathrm{~m}$. Na profundidade de 0,0-0,2 $\mathrm{m}$ a FP observou-se valores significativamente maiores para todos os atributos analisados, exceto nESP. O SPD e SPDE não diferiram nas profundidades para nenhum dos atributos, mostrando que a escarificação realizada apenas uma vez no SPD, não foi suficiente para produzir alterações sobre os atributos microbiológicos do solo. Entretanto, o manejo do solo em PC por 20 anos promoveu reduções no CBM e NBM. A RESP não se diferenciou entre os manejos, assim como o nESP. Na análise de componentes principais houve evidente distância, em termos de atributos microbiológicos, entre a FP e as áreas sob manejo. Concluise que os diferentes manejos de solo alteram a microbiota, sendo que, quanto menor a intensidade do manejo (SPD e SPDE) menores são as alterações nos atributos microbiológicos do solo. As práticas de preparo do solo usadas no plantio convencional alteram negativamente a biomassa microbiana do solo, causando reduções no CBM e NBM.

Palavras-chave: Plantio convencional. Carbono microbiano. Quociente metabólico. Micorrizas. Plantio direto.

\section{Introduction}

In the state of Paraná (Brazil), Latosols cover an area of 62,000 hectares, corresponding to $31 \%$ of the territory of the state (BHERING, 2007). These soils are basaltic, weathered, and deep. Moreover, the characteristics of these soils favor agricultural activity and allow using different cultivation and growing systems. The cropping system used is the no-tillage system (NTS), which involves crop rotation, minimum tillage, and permanent soil cover (CASÃO JUNIOR et al., 2012).

Different from the NTS, the conventional tillage system (CTS) is based on using preparation techniques that promote soil mobilization for aeration and decompaction, which consequently decreases the levels of soil organic matter (SOM) and nutrient stock, reduce soil aggregation, and affect microbial biomass (AZIZ et al., 2013; KABIRI et al., 2016).

Although the NTS uses no-tillage or minimal tillage, the use of soil scarifiers has been adopted in these areas, particularly in soils with a clayey texture, to eliminate the possible occurrence of surface compaction after using NTS for several years (ARAÚJO et al., 2004; LLANILLO et al.,
2006). Cortez et al. (2011) observed that scarification produced minimal surface tillage, which helped maintain soil coverage and prevent the inversion of soil layers. In NTS areas, the effect of scarification was evaluated by measuring soil physical attributes (ARAÚJO et al., 2004; CORTEZ et al., 2011; KABIRI et al., 2015), chemicals (RAIESI; KABIRI, 2016), water resources, and crop yield (CAMARA; KLEIN, 2005; SANTOS et al., 2008). Moreover, the effects of scarification on the soil microbiota need to be studied because this soil component is sensitive to environmental changes (OLIVEIRA et al., 2016) and is directly associated with the decomposition of SOM and nutrient dynamics (MOREIRA et al., 2011). The microbiological attributes most commonly used in soil analysis are microbial biomass carbon (MBC), microbial biomass nitrogen $(\mathrm{MBN})$, microbial activity by soil respiration (RESP), metabolic and microbial quotient $\left(q \mathrm{CO}_{2}\right.$ and $\left.q \mathrm{MIC}\right)$, enzyme activity, and the number of spores (NS) of mycorrhizal fungi (ANGELINI et al., 2012). The analysis of these attributes in agricultural areas allows determining soil quality, which in the long term reflects the sustainability of agricultural areas. 
Changes in microbiological attributes in different soil cropping systems were reported by Babujia et al. (2010), who found that 20-year management of a Latosol increased RESP, $q \mathrm{MIC}, \mathrm{MBC}, \mathrm{MBN}$, and total stocks of N and C in the NTS compared with the CTS. Santos et al. (2008) analyzed a standard Oxisol under three distinct cropping systems and observed that the NTS and scarification + leveling grid presented the highest MBC values compared with the use of a heavy grid. Raiesi and Kabiri (2016) evaluated MBC, MBN, RESP, and enzyme activity and concluded that soil quality was better in the NTS using a soil scarifier compared to the CTS. Ferreira et al. (2017) observed that MBC and $q \mathrm{CO}_{2}$ values using the NTS for 5 years were similar to those in the native vegetation area. These studies demonstrate the importance of adopting conservationist farming systems that are essential for maintaining or improving soil quality. Therefore, considering that management systems affect soil microbiota and consequently soil quality, the objective of this study was to evaluate changes in microbiological attributes of Red Latosol under different cropping systems.

\section{Materials and Methods}

\section{Study area and sampling}

The study areas corresponded to a commercial agricultural crop of approximately 400 ha located in the municipality of Bela Vista do Paraíso, State of Paraná, Brazil (22 $57^{\prime} \mathrm{LS}, 51^{\circ} 11^{\prime}$ LO). According to the classification of Köppen-Geiger, the climate of the region is type Cfa - humid subtropical and mesothermic - with a mean annual precipitation of $1,529 \mathrm{~mm}$, the predominance of rainfall from October to March, mean temperature of $21.4^{\circ} \mathrm{C}$, and relative humidity of $69.9 \%$ (CAVIGLIONE et al., 2000). The soil was classified as Dystroferric Red Latosol (SANTOS et al., 2013) (Rhodic Ferralsol) with clay contente ranging from 675 to $740 \mathrm{~g} \mathrm{~kg}^{-1}$ (Table 1).

Table 1. Granulometric and chemical composition of a Dystroferric Red Latosol managed in a no-tillage system (NTS), scarified no-tillage system (SNTS), conventional tillage system (CTS), relative to a primary forest (PF) at depths of $0.0-0.1,0.1-0.2$ and $0.2-0.3 \mathrm{~m}$.

\begin{tabular}{|c|c|c|c|c|c|c|c|c|c|c|}
\hline \multirow{3}{*}{ Management } & \multicolumn{3}{|c|}{ Granulometry } & \multicolumn{7}{|c|}{ Chemical composition } \\
\hline & Clay & Sand & Silt & $\mathrm{pH}$ & $\mathrm{C}$ & $\mathrm{P}$ & $\mathrm{K}^{+}$ & $\mathrm{Ca}^{2+}$ & $\mathrm{Mg}^{2+}$ & $\mathrm{Al}^{3+}$ \\
\hline & \multicolumn{3}{|c|}{$\mathrm{g} \mathrm{kg}^{-1}$} & \multicolumn{2}{|r|}{$\mathrm{g} \mathrm{dm}^{-3}$} & $\mathrm{mg} \mathrm{dm}^{-3}$ & \multicolumn{4}{|c|}{$\mathrm{cmol}_{\mathrm{c}} \mathrm{dm}^{-3}$} \\
\hline & \multicolumn{10}{|c|}{$0.0-0.1 \mathrm{~m}$} \\
\hline $\mathrm{PF}$ & 675 & 135 & 190 & 5.6 & 34.3 & 2.3 & 0.6 & 10.5 & 2.8 & 0.0 \\
\hline NTS & 735 & 150 & 115 & 5.6 & 21.9 & 7.9 & 0.6 & 6.7 & 2.5 & 0.0 \\
\hline SNTS & 735 & 150 & 115 & 5.5 & 22.8 & 7.5 & 0.5 & 7.4 & 2.9 & 0.0 \\
\hline \multirow[t]{2}{*}{ CTS } & 700 & 125 & 175 & 6 & 15.8 & 14.5 & 0.7 & 9.2 & 2.7 & 0.0 \\
\hline & \multicolumn{10}{|c|}{$0.1-0.2 \mathrm{~m}$} \\
\hline $\mathrm{PF}$ & 690 & 130 & 180 & 5.4 & 22.8 & 0.8 & 0.4 & 7.1 & 2.8 & 0.0 \\
\hline NTS & 730 & 160 & 110 & 5.7 & 14.8 & 1.2 & 0.2 & 6.9 & 2.2 & 0.0 \\
\hline SNTS & 730 & 160 & 110 & 5.6 & 16.0 & 1.2 & 0.2 & 6.3 & 2.2 & 0.0 \\
\hline \multirow[t]{2}{*}{ CTS } & 710 & 120 & 170 & 6.1 & 9.5 & 2.6 & 0.3 & 8.5 & 2.5 & 0.0 \\
\hline & \multicolumn{10}{|c|}{$0.2-0.3 \mathrm{~m}$} \\
\hline $\mathrm{PF}$ & 700 & 170 & 130 & 5.1 & 15.9 & 0.6 & 0.2 & 4.8 & 2.7 & 0.0 \\
\hline NTS & 730 & 160 & 110 & 5.8 & 9.9 & 1.2 & 0.1 & 6.1 & 1.8 & 0.0 \\
\hline SNTS & 730 & 160 & 110 & 5.7 & 11.8 & 1.4 & 0.1 & 6.0 & 1.7 & 0.0 \\
\hline CTS & 740 & 130 & 130 & 5.9 & 8.3 & 2.4 & 0.1 & 9.2 & 2.6 & 0.0 \\
\hline
\end{tabular}

$\mathrm{pH}=\mathrm{H}_{2} \mathrm{O} ; \mathrm{C}=$ Walkley- Black; P e K $=$ Mehlich 1; $\mathrm{Ca}^{2+}, \mathrm{Mg}^{2+}$ e $\mathrm{Al}^{3+}=\mathrm{KCl} 1,0 \mathrm{~mol} \mathrm{~L}^{-1}$. 
The soil cropping systems practiced in the area were the no-tillage system (NTS), conventional tillage system (CTS), and a scarified no-tillage system (SNTS), maintained for 20 years.

The area of the property under the NTS comprised 209 ha of the total area. In this area, crop was cultivated over the residues of the previous crop in a rotation system using maize (Zea mays), soybean (Glycine max), and wheat (Triticum aestivum) for grain harvesting; canola (Brassica napus), oats (Avena sativa), rye (Secale cereale), and triticale (Triticosecale) were cultivated as winter cover crops in alternation with wheat.

The area with the CTS occupied 190 ha, and its preparation before summer sowing in a 20 -year period was based on subsoiling $(\sim 0.35 \mathrm{~m})$ and plowing followed by harrowing $(\sim 0.15 \mathrm{~m})$, and crop succession with corn, soybean, and wheat.

A total of 5 ha of the area under the SNTS was scarified, constituting the SNTS area, and cultivated with the same crop rotation described for the NTS area. Scarification was performed once at a depth of $0.30 \mathrm{~m}$ after harvesting the summer crop (soybean).

In the entire study area, soil acidity was corrected by applying $1030 \mathrm{~kg} \mathrm{ha}^{-1}$ of limestone with $\mathrm{MgO}$ $>12 \%$ to the soil surface during the off-season (wheat/soybean) when base saturation (V\%) was $<50 \%$. Fertilization was performed according to the needs of the crops following the recommendations of Raij et al. (1996).

A primary forest (PF) fragment with natural soil conditions located in the Atlantic Forest domain adjacent to the experimental area was used as a reference.

Soil samples were collected in 1-ha areas delimited in each management system and the PF. Five sampling sites were determined equidistantly and arranged in a zig-zag, and five subsamples circularly distributed around each site were collected to form a composite sample. Soil samples were collected at depths of $0.0-0.1,0.1-0.2$ and $0.2-0.3 \mathrm{~m}$. Sampling was performed before sowing the winter crop (wheat), which in the SNTS corresponded to a period of 30 days after scarification.

\section{Chemical analysis}

The soil chemical attributes were evaluated as described by Pavan et al. (1992). The samples were dried at $60{ }^{\circ} \mathrm{C}$ for 24 hours, then crushed and sieved in a 2-mm sieve. The levels of exchangeable $\mathrm{Ca}^{2+}$, $\mathrm{Mg}^{2+}$, and $\mathrm{Al}^{3+}$ in the soil were extracted with 1.0 mol L-1 of $\mathrm{KCl}$. Exchangeable $\mathrm{Ca}^{2+}$ and $\mathrm{Mg}^{2+}$ were measured by atomic absorption spectrophotometry, and $\mathrm{Al}^{3+}$ was measured by titration with sodium hydroxide $(\mathrm{NaOH})$. Available $\mathrm{P}$ and exchangeable $\mathrm{K}^{+}$were extracted using Mehlich $^{-1}$ extractant solution and quantified by spectrophotometry at an absorbance of $630 \mathrm{~nm}$ and flame photometry, respectively. Total organic carbon (TOC) was measured by oxidizing the soil using potassium dichromate $\left(\mathrm{K}_{2} \mathrm{Cr}_{2} \mathrm{O}_{7}\right)$ in sulfuric medium and subsequent titration using ferrous sulfate $\left(\mathrm{FeSO}_{4}\right)$. The $\mathrm{pH}$ was determined in a suspension of soil and distilled water at a ratio of $1: 2.5$. The results of soil and chemical analyses are presented in Table 1.

\section{Microbiological analysis}

MBC was determined using the fumigation and incubation methods of Jenkinson and Powlson (1976) with modifications. Briefly, 20 grams of soil samples fumigated and non-fumigated with chloroform were incubated in the dark for 3 days at $25{ }^{\circ} \mathrm{C}$. The released $\mathrm{CO}_{2}$ was collected in a 1.0 mol $\mathrm{L}^{-1}$ solution of $\mathrm{NaOH}$ and quantified in the Flow Injection Analysis (FIA) system. MBC was calculated by applying a $\mathrm{K}_{\mathrm{C}}$ of 0.45 (JENKINSON; LADD, 1981). RESP corresponded to $\mathrm{CO}_{2}$ levels obtained from non-fumigated samples during the incubation period. The metabolic quotient $\left(q \mathrm{CO}_{2}\right)$ was obtained by calculating the RESP/MBC ratio. MBN was extracted using the method described by Brookes et al. (1985) and subsequently determined by colorimetry according to Keeney and Nelson 
(1982) using a correction factor $\left(\mathrm{K}_{\mathrm{N}}\right)$ of 0.54 .

The number of spores (NS) of arbuscular mycorrhizal fungi (AMF) was quantified using the wet sieving method according to the methodology described by Gerdemann and Nicolson (1963). After extraction, the spores were washed four times in water and transferred to plates for counting in a stereoscope (400× magnification) as described by Colozzi Filho and Balota (1994), and the value was expressed as the number of spores per $50 \mathrm{~mL}$ of soil.

\section{Statistical analysis}

Statistical analysis was performed using software R version 3.3.3 considering a completely randomized design with five replicates. Data normal distribution was tested using the Shapiro-Wilk test, and the homoscedasticity was assessed using the Bartlett test. The treatments (NTS, CTS, and SNTS) were compared with each other using analysis of variance (ANOVA) followed by Tukey test $(p \leq 0.05)$ and compared with the PF using the t-test $(\mathrm{p} \leq 0.05)$. For principal component analysis (PCA), the data were previously analyzed using the KaiserMeyer-Olklin test and values $>0.5$ were considered as minimum adaptability (HAIR et al., 2006). The components that produced a cumulative variance of $70 \%$ were used.

\section{Results and Discussion}

At a depth of $0.0-0.1 \mathrm{~m}$, the PF presented significantly higher values for all evaluated microbiological attributes, except for NS. Moreover, MBN, MBC, and RESP at $0.1-0.2 \mathrm{~m}$ were higher in PF (Table 2). This result is due to the dynamic equilibrium in an environment with native vegetation, which favors soil microbial biomass because of the continuous and diverse supply of organic materials (leaves, branches, and fruits) at different rates of decomposition (MOREIRA; FAGERIA, 2011; BALOTA, 2017). In addition, the accumulation of litter causes little variation in temperature and humidity (BALOTA, 2017), favoring the development and growth of microorganisms. In turn, soils subjected to agricultural activity present adverse conditions, which usually result in a decrease in the microbial population. In this study, at a depth of $0.0-0.1 \mathrm{~m}$, this condition was reflected by a decrease in MBC by $65 \%$ in the CTS, $53 \%$ in the SNTS, and $48 \%$ in the NTS compared to the PF. At $0.1-0.2$ and $0.2-$ $0.3 \mathrm{~m}$, the decrease in $\mathrm{MBC}$ was $<40 \%$ and $<35 \%$, respectively, in all cropping systems. Lourente et al. (2010) observed a decrease in MBC of $74 \%$ in the NTS and $73 \%$ in the CTS at $0.0-0.1 \mathrm{~m}$ when native vegetation was cut for developing cultivation systems.

In the evaluated cropping systems, there were significant differences in $\mathrm{MBN}, \mathrm{MBC}$, and $q \mathrm{CO}_{2}$ at a depth of $0.0-0.1 \mathrm{~m}$ and significant differences in $\mathrm{MBC}$ at $0.1-0.2 \mathrm{~m}$. At $0.2-0.3 \mathrm{~m}$, there were no significant differences in these parameters between treatments (Table 2), indicating that the soil surface layer was more strongly affected by the different management systems and corroborates the results of D'Andréa et al. (2002) and Paredes Junior et al. (2015).

Regardless of the soil depth, MBC and MBN were higher in the NTS and SNTS compared to the other systems, but these two systems did not differ from each other (Table 2). This result demonstrates the higher accumulation of $\mathrm{C}$ and N in NTS and SNTS areas because of the low oxidation potential. In contrast, intense tillage and low soil cover in CTS areas cause higher variations in temperature and humidity (BALOTA, 2017), promoting the oxidation of C (BAYER et al., 2003). Aziz et al. (2013) reported similar results, wherein MBC values were 2-fold higher in the NTS compared to CTS. With regard to the use of agricultural machinery, Kabiri et al. (2016) studied the use of four tillage equipment and observed that reduced tillage (using a chisel and rotary plows) caused less impact on the soil microbiota than the conventional tillage (using a moldboard and disk plows). 
Table 2. Microbial biomass nitrogen (MBN), microbial biomass carbon (MBC), respirometry (RESP), metabolic quotient $\left(q \mathrm{CO}_{2}\right)$, and number of spores (NS) of mycorrhizal fungi in Dystroferric Red Latosol managed under a notillage system (NTS), scarified no-tillage system (SNTS), conventional tillage system (CTS), relative to a primary forest (PF) at depths of $0.0-0.1,0.1-0.2$ and $0.2-0.3 \mathrm{~m}$. The values correspond to the means of five replicates.

\begin{tabular}{|c|c|c|c|c|c|}
\hline & MBN & $\mathrm{MBC}$ & RESP & $q \mathrm{CO}_{2}$ & NS* \\
\hline Management & \multicolumn{2}{|c|}{$\mathrm{mg} \mathrm{kg}^{-1}$ soil } & mg C-CO $\mathrm{kg}^{-1}$ soil h$^{-1}$ & $\mathrm{mg} \mathrm{C}-\mathrm{CO}_{2} \mathrm{~kg}^{-1} \mathrm{MBC}$ day $^{-1}$ & spores $50 \mathrm{~mL}$ soil $^{-1}$ \\
\hline & \multicolumn{5}{|c|}{$0.0-0.1 \mathrm{~m}$} \\
\hline $\mathrm{PF}$ & $259.32 \mathrm{~A}$ & $956.98 \mathrm{~A}$ & $4.20 \mathrm{~A}$ & $0.10 \mathrm{~A}$ & $1.71 \mathrm{~A}$ \\
\hline NTS & $60.64 \mathrm{Ba}$ & $493.60 \mathrm{Ba}$ & $0.45 \mathrm{Ba}$ & $0.02 \mathrm{Bb}$ & $2.00 \mathrm{Aa}$ \\
\hline SNTS & $80.98 \mathrm{Ba}$ & $449.64 \mathrm{Ba}$ & $0.47 \mathrm{Ba}$ & $0.03 \mathrm{Bb}$ & $2.75 \mathrm{Aa}$ \\
\hline \multirow[t]{2}{*}{ CTS } & $39.24 \mathrm{Bb}$ & $333.54 \mathrm{Bb}$ & $0.85 \mathrm{Ba}$ & $0.06 \mathrm{Ba}$ & $2.96 \mathrm{Ba}$ \\
\hline & \multicolumn{5}{|c|}{$0.1-0.2 \mathrm{~m}$} \\
\hline $\mathrm{PF}$ & $61.92 \mathrm{~A}$ & $574.35 \mathrm{~A}$ & $1.04 \mathrm{~A}$ & $0.04 \mathrm{~A}$ & $1.93 \mathrm{~A}$ \\
\hline NTS & $28.82 \mathrm{Ba}$ & $438.60 \mathrm{Ba}$ & $0.35 \mathrm{Ba}$ & $0.02 \mathrm{Aa}$ & $1.60 \mathrm{Aa}$ \\
\hline SNTS & $29.97 \mathrm{Ba}$ & $449.20 \mathrm{Aa}$ & $0.40 \mathrm{Ba}$ & $0.02 \mathrm{Aa}$ & $1.73 \mathrm{Aa}$ \\
\hline \multirow[t]{2}{*}{ CTS } & $21.23 \mathrm{Ba}$ & $355.29 \mathrm{Bb}$ & $0.29 \mathrm{Ba}$ & $0.02 \mathrm{Aa}$ & $1.71 \mathrm{Aa}$ \\
\hline & \multicolumn{5}{|c|}{$0.2-0.3 \mathrm{~m}$} \\
\hline $\mathrm{PF}$ & $24.78 \mathrm{~A}$ & $333.68 \mathrm{~A}$ & $0.45 \mathrm{~A}$ & $0.03 \mathrm{~A}$ & $0.91 \mathrm{~A}$ \\
\hline NTS & $24.18 \mathrm{Aa}$ & $334.55 \mathrm{Aa}$ & $0.30 \mathrm{Aa}$ & $0.02 \mathrm{Aa}$ & $1.66 \mathrm{Aa}$ \\
\hline SNTS & $30.52 \mathrm{Aa}$ & $318.52 \mathrm{Aa}$ & $0.46 \mathrm{Aa}$ & $0.03 \mathrm{Aa}$ & $1.73 \mathrm{Aa}$ \\
\hline CTS & $17.05 \mathrm{Ba}$ & $225.43 \mathrm{Aa}$ & $0.38 \mathrm{Aa}$ & $0.04 \mathrm{Aa}$ & $1.48 \mathrm{Aa}$ \\
\hline
\end{tabular}

Uppercase letters compare each tillage system with the primary forest (PF) at the same soil depth using the $t$-test ( $\leq \leq 0.05$ ). Lowercase letters compare the soil cropping systems at the same soil depth using Tukey's test ( $\mathrm{p} \leq 0.05)$. MBN values at a depth of 0.0 - $0.1 \mathrm{~m}$ were tested using non-parametric statistics (Kruskal Wallis test). *Data transformed into $\sqrt{ }(\mathrm{NS}+0.5)$.

Microbial biomass is usually more abundant and more active in the NTS compared to the CTS (FERREIRA et al., 2010; BABUJIA et al., 2010; AZIZ et al., 2013) because of non-tillage, crop rotation due to the rhizospheric effect, and the presence of straw, which provides organic $\mathrm{C}$ to the microbial biomass. In addition, the NTS promotes higher aggregation and higher aggregate stability and maintains or increases the levels of organic matter (LLANILLO et al., 2006), creating habitats favorable to microbial development. In contrast, the CTS separates macroaggregates, resulting in loss of microbial habitats (KIHARA et al., 2012; KABIRI et al., 2016).

The analyzed attributes were not significantly different between the SNTS and NTS. This lack of effect is usually attributed to two reasons. In this study, scarification was performed only once and, as reported by Kabiri et al. (2016), the effect of soil tillage on microbial biomass is more pronounced when systems are established for at least 6 years. It is known that changes in soil structure directly affect microbial habitats (SILVA et al., 2014). For this reason, it is possible that microbial habitats, which originate primarily from macroaggregates, were not significantly affected in the SNTS. The second reason is that soil samples were collected 30 days after scarification and part of the microbial activity may have been reestablished in this period.

Similar results were reported by Silva et al. (2014), who evaluated the effect of soil structure on microbial biomass in a 22-year study using Red Latosol and observed that the morphologically homogeneous areas were less compact and more porous in the NTS and SNTS, which resulted in a $20 \%$ increase in $\mathrm{MBC}$ and $51 \%$ increase in $\mathrm{MBN}$ 
in these two systems compared to the CTS. This result confirms the hypothesis that changes in soil structure may be correlated with changes in microbial biomass.

Principal component analysis (PCA) was used to assess the relationship between the different cropping systems and microbiological attributes of the soil. PCA results indicated that the principal components (PCs) at a depth of $0.0-0.1 \mathrm{~m}$ discriminated $92.7 \%$ of data variability $(72.7 \%$ for PC1 and $20 \%$ for PC2) (Figure 1a) and that the contribution of PCs at the $0.1-0.2 \mathrm{~m}$ layer was $80.6 \%$ (Figure $1 \mathrm{~b}$ ). Figures $1 \mathrm{a}$ and $1 \mathrm{~b}$ showed that the ellipse encompassing the points in the three soil management systems was associated with NS. At the $0.2-0.3$ m layer, the contribution of PCs was $70.5 \%$ (Figure 1c) and the three cropping systems did not form a single cluster opposite to PF. MBN, MBC, and RESP were more closely grouped with the $\mathrm{PF}$ in the $\mathrm{X}$-axis, whereas the NS was more closely group with the management systems in the Y-axis, leading to the formation of two clusters (Figure 1). The weight of the eigenvectors used in the interpretation of each $\mathrm{PC}$ was higher than 0.5 , and this value is considered significant for PCA (Table 3). At depths of up to 0.2 $\mathrm{m}$, the managed areas formed a cluster opposite to PF (Figure 1), as determined using the t-test (Table 2).

In this study, there was no difference in RESP between the soil cropping systems. However, RESP in these systems was significantly different from $\mathrm{PF}$ (Table 2), which had the highest mean (4.2 $\mathrm{mg} \mathrm{C}-\mathrm{CO}_{2}$ $\mathrm{kg}^{-1}$ soil $\mathrm{h}^{-1}$ ), indicating higher microbiological activity. This result is different from that found by Ferreira et al. (2010), wherein RESP was decreased due to soil tillage. The range of RESP values was similar to that found by Mercante et al. (2008) in the NTS and CTS in Argisols, and by Ferreira et al. (2017) in Red Latosols of the Cerrado.

The $q \mathrm{CO}_{2}$ values were significantly different at a depth of $0.0-0.1 \mathrm{~m}$, with values of 0.02 and
$0.10 \mathrm{mg} \mathrm{C}-\mathrm{CO}_{2} \mathrm{~kg}^{-1} \mathrm{MBC} \mathrm{day}^{-1}$ (Table 2) in the NTS and PF, respectively. Santos et al. (2004) and Fialho et al. (2006) reported higher $q \mathrm{CO}_{2}$ values under natural soil conditions, and this is because of the presence of easily assimilable substrates for microbial development. The $q \mathrm{CO}_{2}$ in the CTS was $0.06 \mathrm{mg} \mathrm{C}-\mathrm{CO}_{2} \mathrm{~kg}^{-1} \mathrm{MBC}$ day $^{-1}$, indicating higher $\mathrm{CO}_{2}$ losses in this environment compared to the NTS and SNTS because the microbial population in the CTS may oxidize $\mathrm{C}$ for soil maintenance and adaptation (ISLAM; WEIL, 2000). Similar results were reported by Lourente et al. (2010), wherein higher $q \mathrm{CO}_{2}$ values were obtained in the management system under the native vegetation, followed by the CTS, as observed in the present study.

There were no significant differences in NS between the cropping systems at the analyzed depths (Table 2). However, there was a significant difference in the NS between the PF and CTS. This result can be related to the chemical composition of the soil, which is strongly correlated with the presence of AMF (ANGELINI et al., 2012; BALOTA, 2017). There was a significant correlation between the NS and the levels of available $\mathrm{P}$ of the soil by the Spearman test $(r=0.59, p \leq 0.05)$. The PF had the lowest levels of available P in the soil, and consequently lower NS (Table 1), and a similar result was observed using PCA, in which the NS was grouped in the Y-axis with the management systems (Figure 1) that presented the highest levels of available P, opposite to PF (X-axis), which had the lowest levels of available $\mathrm{P}$ at the three soil depths evaluated (Table 1). In addition, plowing and harrowing in the CTS, scarification in the SNTS, and the discs of the plow in the NTS during sowing can disrupt AMF hyphae by inducing sporulation, increasing the NS in managed areas. Colozzi Filho et al. (1999) reported that this result was because spores are resistance structures, and AMF subjected to stressful conditions producing spores as a survival strategy. 
Figure 1. Principal components analysis (PCA) for soil microbiological attributes in primary forest (PF), no-tillage system (NTS), scarified no-tillage system (SNTS), and conventional tillage system (CTS). a, depth of $0.0-0.1 \mathrm{~m} ; \mathrm{b}$, depth of $0.1-0.2 \mathrm{~m}$; c, depth of $0.2-0.3 \mathrm{~m}$.
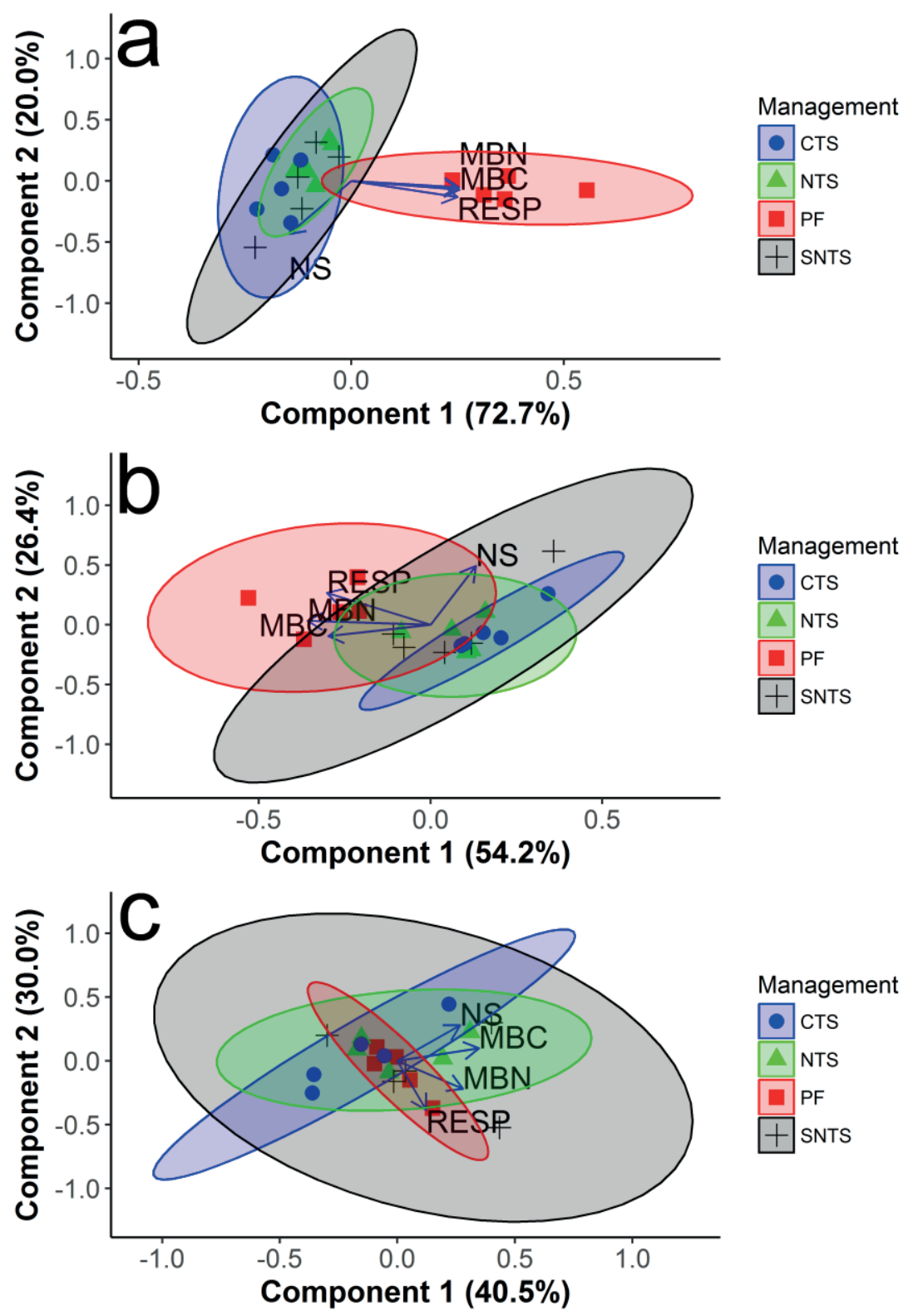

Management

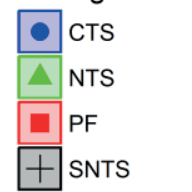

$\mathrm{MBC}=$ microbial biomass carbon, $\mathrm{MBN}=$ microbial biomass nitrogen, RESP $=$ soil respirometry, NS $=$ number of spores of mycorrhizal fungi. Ellipses represent the $95 \%$ confidence interval. 
Table 3. Values of eigenvectors obtained in the principal component analysis for microbial biomass nitrogen (MBN), microbial biomass carbon (MBC), respirometry (RESP), and number of spores (NS) of mycorrhizal fungi.

\begin{tabular}{|c|c|c|c|c|}
\hline \multirow{2}{*}{ Attributes } & $\mathrm{PC} 1$ & PC2 & $\mathrm{PC} 3$ & $\mathrm{PC} 4$ \\
\hline & \multicolumn{4}{|c|}{$0.0-0.1 \mathrm{~m}$} \\
\hline MBN & $\underline{0.549}$ & -0.113 & 0.817 & 0.133 \\
\hline MBC & $\underline{0.552}$ & -0.153 & -0.498 & 0.651 \\
\hline RESP & $\underline{0.541}$ & -0.282 & -0.282 & -0.740 \\
\hline \multirow[t]{2}{*}{ NS } & -0.318 & $\underline{-0.940}$ & - & 0.100 \\
\hline & \multicolumn{4}{|c|}{$0.1-0.2 \mathrm{~m}$} \\
\hline MBN & -0.628 & - & -0.205 & 0.748 \\
\hline $\mathrm{MBC}$ & $\underline{-0.521}$ & -0.165 & 0.813 & -0.202 \\
\hline RESP & $\underline{-0.529}$ & 0.471 & -0.390 & -0.588 \\
\hline \multirow[t]{2}{*}{ NS } & 0.231 & $\underline{0.864}$ & 0.382 & 0.231 \\
\hline & \multicolumn{4}{|c|}{$0.2-0.3 \mathrm{~m}$} \\
\hline $\mathrm{MBN}$ & $\underline{0.523}$ & -0.413 & 0.645 & 0.374 \\
\hline MBC & $\underline{0.651}$ & 0.185 & - & -0.736 \\
\hline RESP & 0.229 & $\underline{-0.723}$ & -0.652 & - \\
\hline NS & 0.500 & 0.522 & -0.398 & 0.564 \\
\hline
\end{tabular}

Underlined values $(|0.5|)$ were considered in the interpretation of the results.

\section{Conclusions}

The different soil cropping systems evaluated change microbiological attributes of the soil, particularly in the superficial layer $(0.0-0.1 \mathrm{~m})$. This change was inversely proportional to the degree of soil tillage, and the levels of MBC and MBN were decreased whereas $q \mathrm{CO}_{2}$ levels were increased when the soil was subjected to conventional tillage.

Scarification performed in the no-tillage system in the first year of implantation did not affect the microbiological attributes of the soils.

\section{References}

ANGELINI, G. A. R.; LOSS, A.; PEREIRA, M. G.; TORRES, J. L. R.; SAGGIN JÚNIOR, O. J. Colonização micorrízica, densidade de esporos e diversidade de fungos micorrízicos arbusculares em solo de Cerrado sob plantio direto e convencional. Semina: Ciências Agrárias, Londrina, v. 33, n. 1, p. 117-132, 2012.
ARAÚJO, M. A.; TORMENA, C. A.; INOUE, T. T.; COSTA, A. C. S. Efeitos da escarificação na qualidade física de um Latossolo Vermelho distroférrico após treze anos de semeadura direta. Revista Brasileira de Ciência do Solo, Viçosa, MG, v. 28, n. 3, p. 495-504, 2004.

AZIZ, I.; MAHMOOD, T.; ISLAM, K. R. Effect of long term no-till and conventional tillage practices on soil quality. Soil and Tillage Research, Amsterdam, v. 131, p. 28-35, 2013.

BABUJIA, L. C.; HUNGRIA, M.; FRANCHINI, J. C.; BROOKES, P. C. Microbial biomass and activity at various soil depths in a Brazilian Oxisol after two decades of no-tillage and conventional tillage. Soil Biology and Biochemistry, Elmsford, v. 42, n. 12, p. 2174-2181, 2010.

BALOTA, E. L. Manejo e qualidade biológica do solo. Londrina: Mecenas, 2017. 288 p.

BAYER, C.; MARTIN-NETO, L.; SAAB, S. C. Diminuição da humificação da matéria orgânica de um Cambissolo Húmico em plantio direto. Revista Brasileira de Ciência do Solo, Viçosa, MG, v. 27, n. 3, p. 537-544, 2003.

BHERING, S. B. Mapa de solos do Estado do Paraná. Rio de Janeiro: EMBRAPA, 2007. 73 p. 
BROOKES, P. C.; LANDMAN, A.; PRUDEN, G.; JENKINSON, D. S. Chloroform fumigation and the release of soil nitrogen: a rapid direct extraction method to measure microbial biomass nitrogen in soil. Soil Biology and Biochemistry, Elmsford, v. 17, n. 6, p. 837842, 1985.

CAMARA, R. K.; KLEIN, V. A. Escarificação em plantio direto como técnica de conservação do solo e da água. Revista Brasileira de Ciência do Solo, Viçosa, MG, v. 29, n. 5, p. 789-796, 2005.

CASÃO JUNIOR, R.; ARAÚJO, A. G.; LLANILLO, R. F. Plantio direto no Sul do Brasil: fatores que facilitaram a evolução do sistema e o desenvolvimento da mecanização conservacionista. Londrina: IAPAR, 2012. 82 p.

CAVIGLIONE, J. H.; KIIHL, L. R. B.; CARAMORI, P. H.; OLIVEIRA, D. Cartas climáticas do Paraná. Londrina: IAPAR, 2000. Disponível em: <http://www. iapar.br/>. Acesso em: 2 fev. 2017.

COLOZZI FILHO, A.; BALOTA, E. L. Micorrizas arbusculares. In: HUNGRIA, M.; ARAUJO, R. S. (Ed.). Manual de métodos empregados em estudos de microbiologia agrícola. Brasília: EMBRAPA, 1994. p. 383-412.

COLOZZI FILHO, A.; BALOTA, E. L.; ANDRADE, D. S. Microrganismos e processos biológicos no Sistema Plantio Direto. In: SIQUEIRA, J. O.; MOREIRA, F. M. S.; LOPES, A. S.; GUILHERME, L. R. G.; FAQUIN, V.; FUTINI NETO, A. E.; CARVALHO, J. C. (Ed.). Interação fertilidade, biologia do solo e nutrição de plantas. Lavras: SBCS, 1999. p. 487-508.

CORTEZ, J. W.; ALVES A. D. S.; MOURA, R. D.; OLSZEVSKI, N.; NAGAHAMA, H. J. Atributos físicos do Argissolo amarelo do semiárido nordestino sob sistemas de preparo. Revista Brasileira de Ciência do Solo, Viçosa, MG, v. 35, n. 4, p. 1207-1216, 2011.

D'ANDRÉA, A. F.; SILVA, M. L. N.; CURI, N.; SIQUEIRA, J. O.; CARNEIRO, M. A. C. Atributos biológicos indicadores da qualidade do solo em sistemas de manejo na região do cerrado no sul do estado de Goiás. Revista Brasileira de Ciência do Solo, Viçosa, MG, v. 26, n. 4, p. 913-924, 2002.

FERREIRA, E. P. B.; SANTOS, H. P. D.; COSTA, J. R.; DE-POLLI, H.; RUMJANEK, N. G. Microbial soil quality indicators under different crop rotations and tillage management. Revista Ciência Agronômica, Fortaleza, v. 41, n. 2, p. 177-183, 2010.

FERREIRA, E. P. B.; STONE, L. F.; MARTINDIDONET, C. C. População e atividade microbiana do solo em sistema agroecológico de produção. Revista
Ciência Agronômica, Fortaleza, v. 48, n. 1, p. 1- 22, 2017.

FIALHO, J. S.; GOMES, V. F. F.; OLIVEIRA, T. S. de; SILVA JÚNIOR, J. M. T. Indicadores da qualidade do solo em áreas sob vegetação natural e cultivo de bananeiras na Chapada do Apodi-CE. Revista Ciência Agronômica, Fortaleza, v. 37, n. 3, p. 250-257, 2006.

GERDEMANN, J. W. NICOLSON, T. H. Spores of mycorrhizal endogamous species extracted from soil by wet sieving and decanting. British Mycological Society Transactions, London, v. 46, n. 2, p. 235-244, 1963.

HAIR, J. R.; BLACK, W. C.; BABIN, B. J.;ANDERSON, R. E.; TATHAM, R. L. Multivariate data analysis. $6^{\text {th }} \mathrm{ed}$. Upper Saddle River: Pearson Prentice Hall, 2006. 761 p.

ISLAM, K. R.; WEIL, R. R. Land use effects on soil quality in a tropical forest ecosystem of Bangladesh. Agriculture, Ecosystems and Environment, Amsterdam, v. 79, n. 1, p. 9-16, 2000.

JENKINSON, D. S.; LADD, J. N. Microbial biomass in soil: measurement and turnover. In: PAUL, E. A.; LADD, J. M. (Ed.). Soil biochemistry. New York: Marcel Decker, 1981. v. 5, p. 415-471.

JENKINSON, D. S.; POWLSON, D. S. The effects of biocidal treatments on metabolism in soil. V-A method for measuring soil biomass. Soil Biology and Biochemistry, Elmsford, v. 8, n. 3, p. 209-213, 1976.

KABIRI, V.; RAIESI, F.; GHAZAVI, M. A. Six years of different tillage systems affected aggregate-associated SOM in a semi-arid loam soil from Central Iran. Soil and Tillage Research, Amsterdam, v. 154, p. 114-125, 2015.

KABIRI, V.; RAIESI, F.; GHAZAVI, M. A. Tillage effects on soil microbial biomass, SOM mineralization and enzyme activity in a semi-arid Calcixerepts. Agriculture, Ecosystems and Environment, Amsterdam, v. 232, p. 73-84, 2016.

KEENEY, D. R.; NELSON, D. W. Nitrogen. Inorganic forms. In: PAGE, A. L. (Ed.). Method of soil analysis chemical and microbiological. $2^{\text {th }}$ ed. Madison: American Society of Agronomy, 1982. p. 643-693.

KIHARA, J.; MARTIUS, C.; BATIONO, A.; THUITA, M.; LESUEUR, D.; HERRMANN, L.; AMELUNG, W.; VLEK, P. L.G. Soil aggregation and total diversity of bacteria and fungi in various tillage systems of sub-humid and semi-arid Kenya. Applied Soil Ecology, Amsterdam, v. 58 , p. 12-20, 2012.

LLANILLO, R. F.; RICHART, A.; TAVARES FILHO, J.; GUIMARÃES, M. F.; FERREIRA, R. R. Evolution of physical properties of soils according to tillage systems on annual crops. Semina: Ciências Agrárias, Londrina, v. 27, n. 2, p. 205-220, 2006. 
LOURENTE, E. R. P.; MERCANTE, F. M.; MARCHETTI, M. E.; SOUZA, L. C. F.; SOUZA, C. M. A.; GONÇALVES, M. C.; SILVA, M. A. G. Crop rotation and soil biochemical and microbiological characteristics and corn crop yield. Semina: Ciências Agrárias, Londrina, v. 31, n. 4, p. 829-842, 2010.

MERCANTE, F. M.; SILVA, R. F.; FRANCELINO, S. F.; CAVAlHEIRO, J. C. T.; OTSUBO, A. A. Biomassa microbiana, em um Argissolo Vermelho, em diferentes coberturas vegetais, em área cultivada com mandioca. Acta Scientiarum Agronomy, Maringá, v. 30, n. 4, p. 479485, 2008.

MOREIRA, A.; FAGERIA, N. K. Changes in Soil properties under two different management systems in the Western Amazon. Communications in Soil Science and Plant Analysis, Philadelphia, v. 42, n. 21, p. 26662681, 2011.

MOREIRA, A.; FAGERIA, N. K.; GARCIA y GARCIA, A. Soil Fertility, Mineral nitrogen, and microbial biomass in upland soils of the Central Amazon under different plant covers. Communications in Soil Science and Plant Analysis, Philadelphia, v. 42, n. 6, p. 694-705, 2011.

OLIVEIRA, S. P.; CANDIDO, M. J. D.; WEBER, O. B.; XAVIER, F. A. S.; ESCOBAR, M. E. O.; OLIVEIRA, T. $\mathrm{S}$. Conversion of forest into irrigated pasture I. Changes in the chemical and biological properties of the soil. Catena, Amsterdam, v. 137, p. 508-516, 2016.

PAREDES JUNIOR, F.; PORTILHO, I. I. R.; MERCANTE, F. M. Microbiological attributes of the soil under cultivation of sugar cane with and without burning straw. Semina: Ciências Agrárias, Londrina, v. 36, n. 1, p. 151-164, 2015.
PAVAN, M. A.; BLOCH, M. F.; ZEMPULSKI, H. C.; MIYAZAWA, M.; ZOCOLER, D. C. Manual de análise química de solo e controle de qualidade. Londrina: IAPAR, 1992. $40 \mathrm{p}$.

RAIESI, F.; KABIRI, V. Identification of soil quality indicators for assessing the effect of different tillage practices through a soil quality index in a semi-arid environment. Ecological Indicators, v. 71, p. 198-207, 2016.

RAIJ, B. V.; CANTARELlA, H.; QUAGGIO, J. A.; FURLANI, A. M. C. (Ed.). Recomendações de adubação e calagem para o Estado de São Paulo. Campinas: Instituto Agronômico, 1996. 285 p.

SANTOS, H. G.; JACOMINE, P. K. T.; ANJOS, L. H. C.; OLIVEIRA, V. A.; LUMBRERAS, J. F.; COELHO, M. R.; ALMEIDA, J. A.; CUNHA, T. J. F.; OLIVEIRA, J. B. Sistema brasileiro de classificação de solos. 3. ed. Brasília, DF: Embrapa, 2013. 353p.

SANTOS, T. E. B.; NAKAYAMA, F. T.; ARF, O.; CASSIOLATO, A. M. R. Alterações microbiológicas, de fertilidade e de produtividade do arroz de terras altas em diferentes manejos de solo e água. Acta Scientiarum. Agronomy, Maringá, v. 30, n. 2, p. 203-209, 2008.

SANTOS, V. B.; CASTILHOS, D. D.; CASTILHOS, R. M. V.; PAUletTO, E. A.; GOMES, A. S.; SIlVA, D. G. Biomassa, atividade microbiana e teores de carbono e nitrogênio totais de um Planossolo sob diferentes sistemas de manejo. Revista Brasileira de Agrociência, Pelotas, v. 10, n. 3, p. 333-338, 2004.

SILVA, A. P.; BABUJIA, L. C.; FRANCHINI, J. C.; RALISCH, R.; HUNGRIA, M.; GUIMARÃES, M. F. Soil structure and its influence on microbial biomass in different soil and crop management systems. Soil and Tillage Research, Amsterdam, v. 142, p. 42-53, 2014. 
